\title{
STRESS TESTING OF THE BANKING SYSTEMS: APPROACH OF UKRAINE
}

\author{
Olena Sobolieva-Tereshchenko \\ Borys Grinchenko Kyiv University, Ukraine \\ Yuliia Zhukova \\ Borys Grinchenko Kyiv University, Ukraine
}

\begin{abstract}
This article deals with scientific publications and recommendations on conducting stress testing. The current stress testing methodology developed by the National Bank of Ukraine (NBU), in accordance with the implementation stages of Basel III recommendations, is also researched.

In this article, we have looked into the specific features of stress testing of the Ukrainian banking system using research from foreign and domestic scholars, as well as data from the NBU. We also investigated the development of methodological approaches for assessing the financial stability of Ukrainian banks from 2014 to 2019.

Scientific-methodical approaches to stress testing the Ukrainian banking system in the context of the banking groups - state-owned, owned by Russia, foreign-owned, and private Ukrainian owned - are analyzed in this article. The influence of these banking groups is disclosed to regulate of financial stability of the banking system (essence). Banks from Eastern Europe and Central Asia have the highest indicators of financial stability in the Ukrainian banking system.

The proposed article presents an improved methodology for determining the level of financial stability of banking groups in terms of a crisis increase in the exchange rate by using the NBU stress testing scenario and the impact of devaluating the national currency.
\end{abstract}

Keywords: bank, exchange rate, Basel III, core capital, regulatory capital

DOI: http://dx.doi.org/10.15549/jeecar.v7i2.358

\section{INTRODUCTION}

The successful functioning of the country's banking system depends on the financial stability of banks operating within its territory. There are three groups of banks with different forms of ownership in Ukraine: state-owned banks, private Ukrainian banks, and foreign banks. The group of banks with foreign capital has a significant influence on the country's banking system. Banks with foreign capital account for $27 \%$ of the total number of banks in 
Ukraine and have forms of ownership from 15 countries.

The effective methodology for estimating the financial stability of banks is also important for the successful functioning of the country's banking system. Stress testing is an effective instrument for estimating the financial stability of banks. The effective methodology of stress testing the banking system must to take into account the features of the country's banking system and constantly evolve to counteract the emerging negative factors of internal and external economic crises.

The Basel III recommendations on banking regulation are important for developing a methodology of Ukrainian stress testing because, in this case, it uses the experiences of foreign European banks. The stress testing of state-owned banks and private Ukrainian banks is also important for developing a methodology of Ukrainian stress testing. It is relevant because the results help to develop and implement a strategy of strengthening the positions of Ukrainian banks, as well as identifying a group of systemically important banks.

The activities of foreign banks in Ukraine are closely linked to the general state of the Ukrainian economy as their national economy. In this way, their banking activities are more valued, drawing attention to the emerging negative factors of internal and external economic crises, especially exposure to currency risks.

Therefore, developing a methodology of stress testing that takes into account changes in exchange rates is a topical issue in the research on financial stability in the banking sector of Ukraine, especially when a group of banks with foreign capital have a significant influence on the country's banking system.

\section{ANALYSIS OF RECENT RESEARCH AND PUBLICATIONS}

The issues of stress testing the banking system have been researched by a sufficient number of foreign and domestic scholars. In particular, foreign experts as such as Covas, Francisco, Ben Rump, and Egon Zakrajsek (2014), and Hirtle, Beverly, Anna Kovner, James Vickery, and Meru
Bhanot (2016), effectively described research of top-down methodologies, which actually applied to stress testing. Research on bottom-up methods is limited, but the models used at regulatory agencies still use "extreme yet plausible" exogenous macroeconomic scenarios to obtain stress-driven results using loan-level data.

The policies of stress-testing in the US, the UK, and the EU are described in research by: Bookstaber, Cetina, Feldberg, Flood, and Glasserman (2014); Sangha and Lin (2013); Schuermann, (2014); Wall (2014); Goldstein (2017); and Kapinos, Mitnik, and Martin (2018).

Ukrainian scientists Diuba and Murina (2015) described the NBU approach to stress testing the Ukrainian banking system, developed in cooperation with the International Monetary Fund (IMF), and per the implementation stages of Basel III recommendations in the field of banking regulation. Besides, Reverchuk, Vladychyn, and Davis (2015) developed recommendations to improve the transparency of the banking sector's functions to activate deposit and credit activity, based on an analysis of foreign banks' tendencies towards development in Ukraine.

Ukrainian scientists have also researched the financial stability of foreign banks in the Ukrainian banking system. Maslennikov, Lomachynska, and Bychkova (2017) substantiated that increasing the number of banks with foreign capital has a positive effect on the adequacy of the regulatory capital of the banking system while increasing the number of banks with national capital has a negative effect. Ramskyi, Loiko, et al. (2017) analyzed the main indicators of Ukrainian banks' financial stability from 2014 through 2017. As a result, they concluded that banks with foreign capital are the most stable in the Ukrainian banking system.

Also, domestic scientists researched the Ukrainian banking system in comparison with the banking systems of other countries. Sobolieva-Tereshchenko (2018) conducted a comparative analysis of the Ukrainian bank card market, as well as its seven neighboring countries, and determined that the Ukrainian and Polish bank card markets are similar. Kichurchak (2019) described the directions and 
factors of the activation of the bank deposits market in Ukraine, determining the intensity of attraction of deposits to the banking systems of Ukraine, Belarus, and Poland.

At the same time, the research appears to leave the door open for improving stress testing scenarios and additional study of the results of different banking groups, including Eastern European and Central Asian banks.

\section{FORMULATION OF ARTICLE'S OBJECTIVES}

The purpose of the article is to research special features and improve approaches to conducting stress testing Ukrainian banks in the context of the implementation of Basel III recommendations on banking regulation, as well as the assessment of stress testing results of different banks' groups under the impact of national currency devaluation.

\section{PRESENTATION OF KEY RESEARCH FINDINGS}

Stress testing is used by the leading central banks of the world as an incentive to improve the quality of internal auditing and risk management in banks. It allows to shift the focus of banking supervision from the traditional analysis of current liquidity states and capitalization to their possible future implications under the influence of extreme events.

The world economic community created a number of documents with recommendations on conducting stress testing. These regulatory acts contain basic recommendations for conducting stress tests, but there is no specific list of actions for their implementation. This allows banks to develop their own stress testing methods based on the proposed principles, taking into account the specifics of their business models. Basic approaches to stress testing are given in Table 1.

Table 1: Comparison of stress testing approaches

\begin{tabular}{|c|c|c|c|c|c|}
\hline Country & UK & USA & EU & UA & Russia \\
\hline Program & $\begin{array}{l}\text { Bank of England } \\
\text { stress test }\end{array}$ & $\begin{array}{l}\text { Dodd-Frank } \\
\text { Act Stress Test } \\
\text { (DFAST) }\end{array}$ & $\begin{array}{l}\text { EU- wide stress } \\
\text { test (EBA) }\end{array}$ & $\begin{array}{l}\text { NBU stress } \\
\text { test }\end{array}$ & $\begin{array}{l}\text { Financial } \\
\text { Sector } \\
\text { Assessment } \\
\text { Program } \\
\text { (FSAP) }\end{array}$ \\
\hline $\begin{array}{l}\text { Number of } \\
\text { Scenarios }\end{array}$ & 3 & 3 & 2 & 2 & 1 \\
\hline Institutions & $\begin{array}{l}7 \text { major UK } \\
\text { banks and } \\
\text { building } \\
\text { societies }\end{array}$ & $31 \mathrm{BHCs}$ & $\begin{array}{l}123 \text { banking } \\
\text { group from } 22 \\
\text { countries }\end{array}$ & 29 UA banks & All banks \\
\hline $\begin{array}{l}\text { Basic } \\
\text { indicators }\end{array}$ & $\begin{array}{l}\text { Oil price, GDP } \\
\text { real and } \\
\text { nominal growth } \\
\text { rate, Pound } \\
\text { sterling to euro } \\
\text { and US dollar } \\
\text { exchange rate } \\
\text { index }\end{array}$ & $\begin{array}{l}28 \text { Basic } \\
\text { indicators, } \\
\text { including } \\
\text { Unemployment } \\
\text { rate, Consumer } \\
\text { price index, } \\
\text { GDP growth } \\
\text { rate, US dollar } \\
\text { to national } \\
\text { currencies }\end{array}$ & $\begin{array}{l}\text { GDP growth } \\
\text { rate, CPI, } \\
\text { Unemployment } \\
\text { rate, } \\
\text { Residential and } \\
\text { commercial } \\
\text { property prices }\end{array}$ & $\begin{array}{l}\text { Change in } \\
\text { real and } \\
\text { nominal GD, } \\
\text { Consumer } \\
\text { price index, } \\
\text { at the end, } \\
\text { Reducing the } \\
\text { rate of UAH } \\
\text { to USD }\end{array}$ & $\begin{array}{l}\text { Oil price, GDP } \\
\text { growth rate, } \\
\text { CPI, } \\
\text { Investment } \\
\text { growth rates in } \\
\text { fixed assets, } \\
\text { Dollar / ruble } \\
\text { exchange rate }\end{array}$ \\
\hline
\end{tabular}

Source: Developed by authors. 
According to the results of the comparison analysis, the indicators GBP to EUR, GBP to USD, USD to national currencies, UAH to USD, USD to RUB are used in approaches to stress testing. Per the recommendations of Basel III, and taking in view the experience of the Bank of England, we propose using the exchange rate EUR/UAH in addition to the basic indicators for stress testing.

Having researched successful foreign experiences, the National Bank of Ukraine also decided to use the stress testing tool to monitor and improve the financial sustainability of the country's banking system. According to the historical retrospective data, two stages of assessing the financial stability of the banking system are distinguished in the formation of the strategy for banking stress testing in Ukraine: the first stage (2014-2017) and the second stage (2018 to present).

According to the scenarios of stress testing Ukrainian banks in 2018-2019, the forecast of real and nominal GDP indicators remained, but the exchange rates on IBM and the rates for raising funds and lending in foreign currency and in national currency were replaced by two other indicators: the consumer price index and the rate of depreciation of UAH to USD.

The role of the baseline scenario is to create a base for comparison between favorable or adverse scenarios. NBU's public forecasts are used for the baseline scenario. The value of the exchange rate for the baseline scenario is based on the Focus Economics consensus forecast. The NBU developed the adverse scenario, and it is based on assumptions of the size of the decline in real GDP per one standard deviation from the baseline forecast and devaluation of the hryvnia to the US dollar.

The scenarios of stress testing Ukrainian banks for 2018 and 2019, unlike the basic macroeconomic scenarios of stress testing from 2013 to 2017, are more unified, systematic, and logically related. Therefore, under the baseline scenario for 2018 and 2019, real GDP figures coincide - 3.4\% (2018) and 2.9\% (2020). The consumer price index at the end of 2020 is planned at $5.0 \%$. Under the adverse scenario, the decline in the rate of UAH to USD, according to the NBU's estimate in 2019, remains at the 2018 level. The rate of depreciation of UAH to USD under the baseline scenario, according to "Focus Economics" estimates, is well below the NBU's forecast under the adverse scenario, indicating that the regulator takes into account the degree of dollarization of the country's economy under the adverse scenario.

Today, Ukraine is integrated into the European banking system and has implemented the recommendations of Basel III. In this way, using the rate of depreciation of UAH to EUR, rather than UAH to USD, in stress testing scenarios is more logical.

As a result of the assessments of banks' resilience in 2018 and 2019, the NBU provided recommendations for achieving the required level of these norms by both increasing the size of capital and restructuring the assets or liabilities of the bank. It has ultimately had a significant positive impact on the stability of the banking system in Ukraine.

For the last five years, the objects of the NBU's stress testing were state-owned and private banks, as well as banks with foreign capital, which together accounted for more than $90 \%$ of the assets in the Ukrainian banking sector. Based on the recommendations of the IMF, and using the Basel II and Basel III methodologies for calculating the credit risk for borrowers, the NBU conducted stress testing on Ukrainian banks in the period between 2014 to 2019. As a result of actions aimed at improving the financial stability of banks and clearing the banking system, the number of banks has decreased by almost double. The change in the number of banks in Ukraine over the last 15 years is shown in Fig.1. 


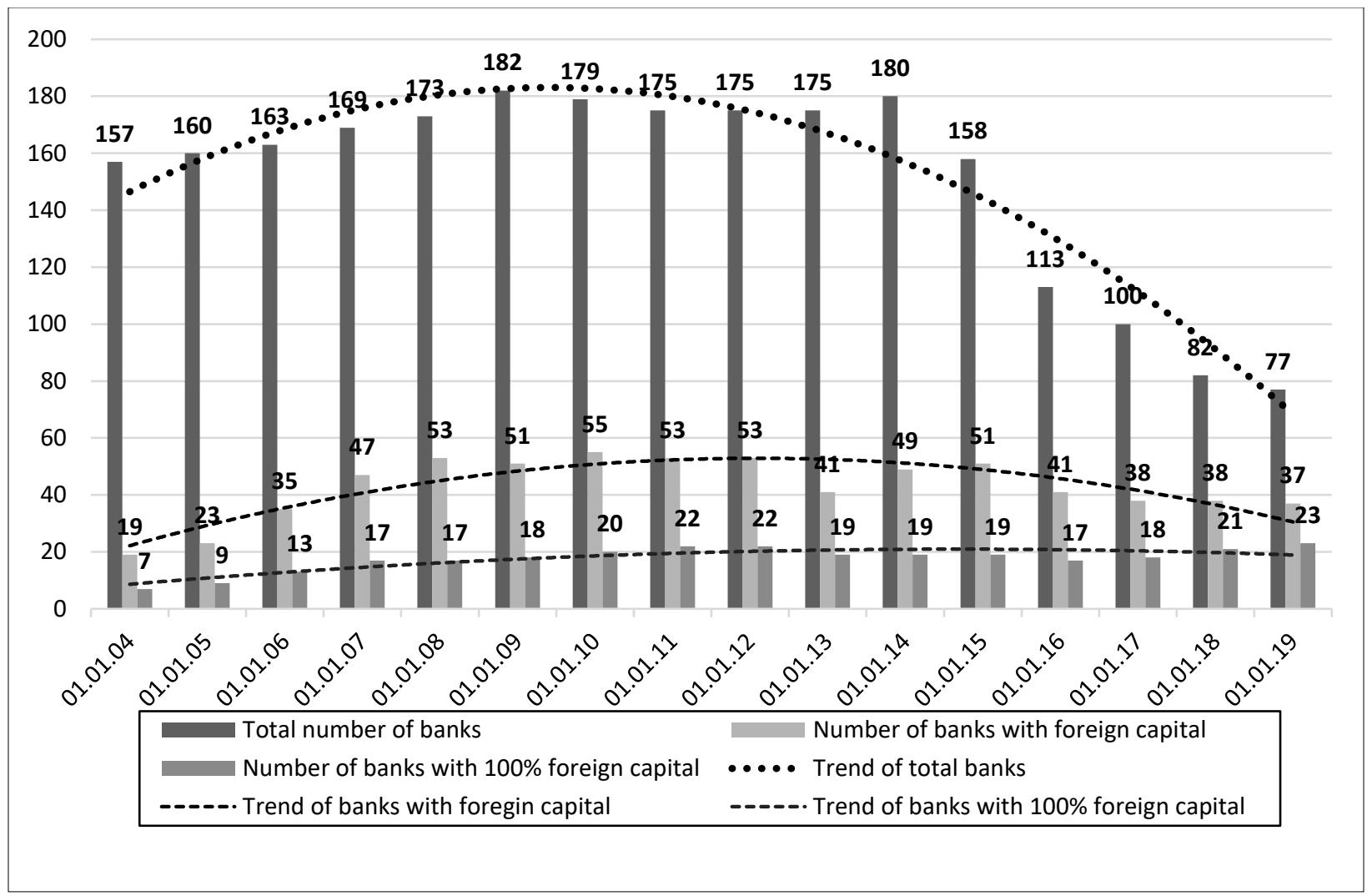

Figure 1: Dynamics of the number of Ukrainian banks in $2014-2019$, un.

Source: based on data 16 .

During these 15 years, the total number of banks in Ukraine and the number of banks with foreign capital followed a different trend - from 2004 to 2014, indicators increased, and from 2014 to 2019 , they decreased. With a generally reduced number of banks in Ukraine, from 180 in 2014 to 77 in 2019 (almost 2.4 times), the number of banks with foreign capital decreased by only 1.37 times. At the same time, over a five-year period, the number of banks with $100 \%$ foreign capital increased by $21 \%$, starting with 19 banks in 2014 to 23 banks in 2019.

From 2014, there have been considerable decreases in the number of banks located in Ukraine. As a result, the share of foreign participation in the Ukrainian banking system has been continuously growing, especially in terms of $100 \%$ foreign capital.

The analyses of the effects of core capital on the Ukrainian banking market shows that until
2019, 21 foreign banks in Ukraine were represented by 15 countries. Among the foreign banks with almost 30\% in core capital in the Ukrainian banking business, they were banks with capital from Russia (Sberbank, Prominvestbank, Bank Forward - 8.30\%), France (Credit Agricole bank and Ukrsibbank- 6.53\%), Cyprus (Alfa-Bank bank and Ukrsotsbank 6.14\%), Austria (Raiffeisen Bank Aval - 5.43\%), and Hungary (OTP Bank - 3.28\%). These banks underwent NBU stress testing in 2018-2019, except for banks with Russian capital.

Notably, Russian banks during post-Soviet extension were densely present in Ukraine, although their share has fallen significantly since 2015. Several banks with Russian capital (VTB Bank, Bank Petrokommerts-Ukraine, BM Bank, Trust Bank) left the Ukrainian market or changed owners (Alfa-Bank) during the last 3 years. 


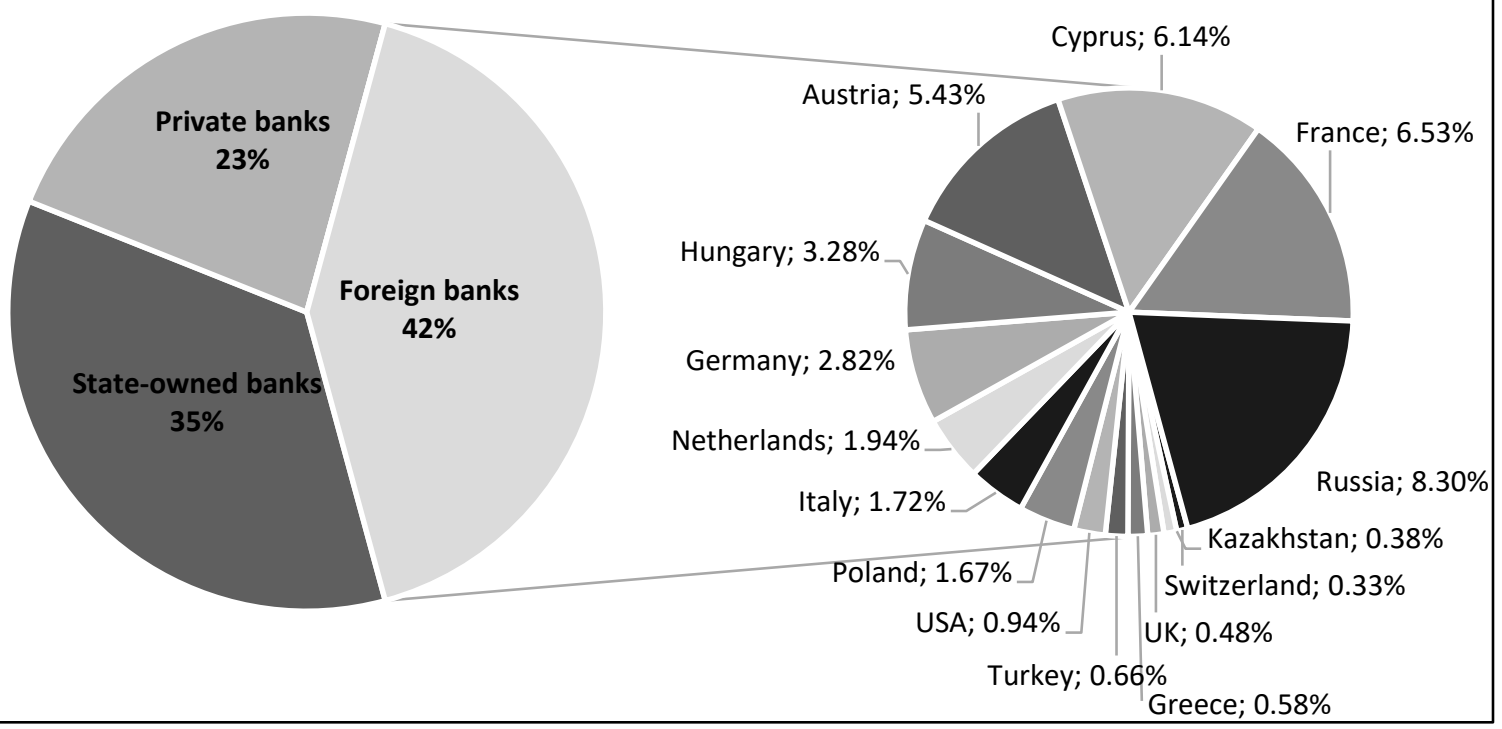

Figure 2: The presence of the foreign banks for the period of $01.01 .2019, \%$

Source: based on data 16.

Moreover, in Ukraine, Eastern European and Central Asian banks represent almost $14 \%$ of banks' core capital, including Russia (8.30\%), Hungary (3.28\%), Poland (1.67\%), and Kazakhstan (0.38\%). Therefore, neighboring countries, as well as other European countries, are active investors in the Ukrainian banking sector. Other neighboring countries, as well as Central Asian countries, are non-active investors in the Ukrainian banking sector, with only the Kazakhstani BTA bank working in Ukraine.

Thus, those 21 foreign banks have important roles in the Ukrainian banking system, especially because they possess about $42 \%$ of the core capital in the Ukrainian banking market. This is the largest indicator among the groups of banks. For example, 5 state-owned banks have $35 \%$, while 51 private Ukrainian banks have only $23 \%$ of the core capital in the Ukrainian banking market.

Foreign banks, among total banks in Ukraine, consisting of $27 \%$, with forms of ownership from 15 countries. The percentage of the number of foreign-owned banks to the number of total banks in these 15 countries is shown in Fig.3.

During these ten years, the number of banks with foreign capital had different trends in these
15 countries, especially in the financial crisis period from 2008 to 2013, and the period after the financial crisis from 2013 to 2018. After the financial crisis, the number of banks with foreign capital decreased in most countries and only increased in Cyprus, Switzerland, and Kazakhstan.

There are different reasons for the growth in the number of foreign banks in these countries. Cyprus is in the offshore zone, and foreign banks there have favorable conditions for development. Switzerland is the center of world banking, and foreign banks have reliable conditions for their activities. Kazakhstan is a buffer zone between China and Europe, as well as a country with a developed oil industry; therefore, foreign banks have many opportunities for their business expansion.

During the years between 2008 and 2018, the number of banks with partial foreign capital decreased in Ukraine, but the number of banks with 100\% foreign capital increased. Ukraine is also a country that has integrated into Eurozone, so foreign banks have new opportunities for business development. 


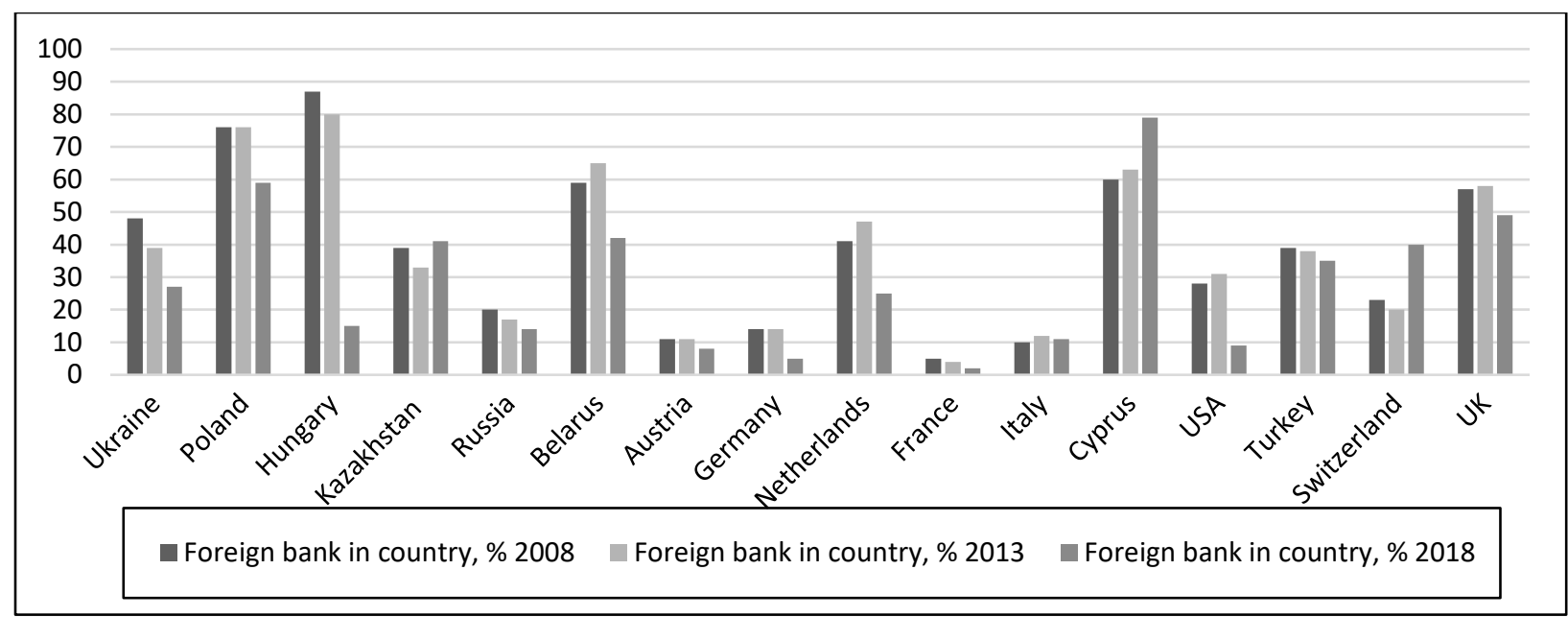

Figure 3. The presence of the foreign banks among total banks 2008-2018, \%

Source: based on data 15,16 .

As such, stress testing banks is an important tool for assessing the financial stability of the banking group from any country, which is developing business, or planning development, in Ukraine. Estimating the status of the core capital (CC) and regulatory capitals (RC) of banks, analyzing the adequacy and needs of banks in terms of capital, and stress testing a group of selected, systemically important banks is an effective method for assessing the stability of the banking sector.

As noted above, the main result of stress testing is the forecast of capital (CC and RC) for each bank for three years, and projected capital needs. The characteristics of the two main scenarious used in stress testing Ukrainian banks are given in Table 2 .

Table 2: Comparative characteristics of norms $\mathrm{H} 2$ and $\mathrm{H} 3$

\begin{tabular}{|c|c|c|}
\hline Indicator & Adequacy ratio of bank's RC (H2) & $\mathrm{CC}$ ratio $(\mathrm{H} 3)$ \\
\hline 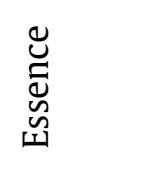 & $\begin{array}{l}\text { Reflects the ability of the bank to timely } \\
\text { and fully pay off its obligations arising } \\
\text { from trade, credit or other monetary } \\
\text { transactions }\end{array}$ & $\begin{array}{l}\text { Shows the level of capital adequacy in } \\
\text { terms of overall activity, regardless of the } \\
\text { size of various bank risks }\end{array}$ \\
\hline 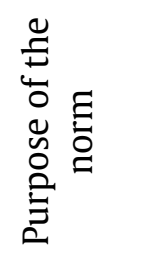 & $\begin{array}{l}\text { Is established to prevent the excessive } \\
\text { transfer of the bank credit risk and the } \\
\text { risk of non-return of bank assets to } \\
\text { creditors and depositors of the bank }\end{array}$ & $\begin{array}{l}\text { Is established to determine the bank's } \\
\text { ability to protect creditors and depositors } \\
\text { from unforeseen losses that may be } \\
\text { incurred by the bank in the course of its } \\
\text { activities depending on the size of various } \\
\text { risks }\end{array}$ \\
\hline 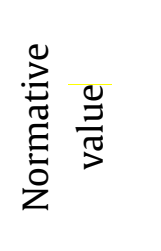 & $\begin{array}{l}\text { Less than } 15 \% \text {; } \\
\text { The next } 12 \text { months - not less than } 12 \% \text {; } \\
\text { After that period - not less than } 10 \% \text {. } \\
\text { For banks that start operating - the first } \\
12 \text { months - not less }\end{array}$ & $\begin{array}{l}\text { _Not less than } 7 \% \\
\text { The Bank forms capital buffers above the } \\
\text { regulatory value of H3 starting: } \\
01.01 .20-0.63 \% ; 01.01 .21-1.25 \% \text {; } \\
01.01 .22-1.88 \% ; 01.01 .23-2.5 \% \text {. }\end{array}$ \\
\hline
\end{tabular}


Table 2. Continuous

\begin{tabular}{|c|c|c|}
\hline 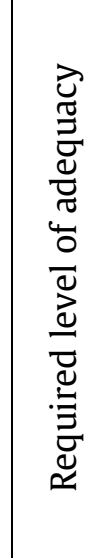 & $\begin{array}{l}\mathrm{H} 2 \\
\quad=\max \left(H 2_{A Q R}\right. \\
\left.\qquad+\frac{\Delta H 2}{\left(R C_{A Q R} / H 2_{A Q R}\right) /\left(R C_{J} / H 3_{J}\right)} ; 10 \%\right) \text {, } \\
\text { where } A Q R \text { is the index reflecting the } \\
\text { value of the result of the first two stages } \\
\text { of assessment of stability; } \mathrm{j} \text { is the index } \\
\text { corresponding to the macroeconomic } \\
\text { scenario (baseline, adverse) and the } \\
\text { forecast year }(1 \mathrm{st}, 2 \text { nd, 3rd), for which } \\
\text { the value of } \triangle H 2 \text { is determined }\end{array}$ & $\begin{array}{l}\text { where } A Q R \text { is the index that reflects the } \\
\text { value of the first two stages of stability } \\
\text { assessment results; } \mathrm{j} \text { is the index } \\
\text { corresponding to the macroeconomic } \\
\text { scenario (baseline, adverse) and the } \\
\text { forecast year (1st, 2nd, 3rd), for which the } \\
\text { value of } \Delta H 3 \text { is determined }\end{array}$ \\
\hline
\end{tabular}

Source: Developed by authors.

The data provided by banks, and the data received by the regulator, based on the results of the asset quality assessment and the eligibility of collateral for bank lending operations, taking into account the adjustments of the bank's financial statements for the reporting year, and the extrapolation of the
Asset Quality Review (AQR), were used to assess banks' resilience in the stress testing of the NBU. The indicators of core capital and regulatory capital, acquired in two different ways, were as close as possible to those of Ukrainian stateowned banks, and very far from those of banks with state-owned Russian capital.

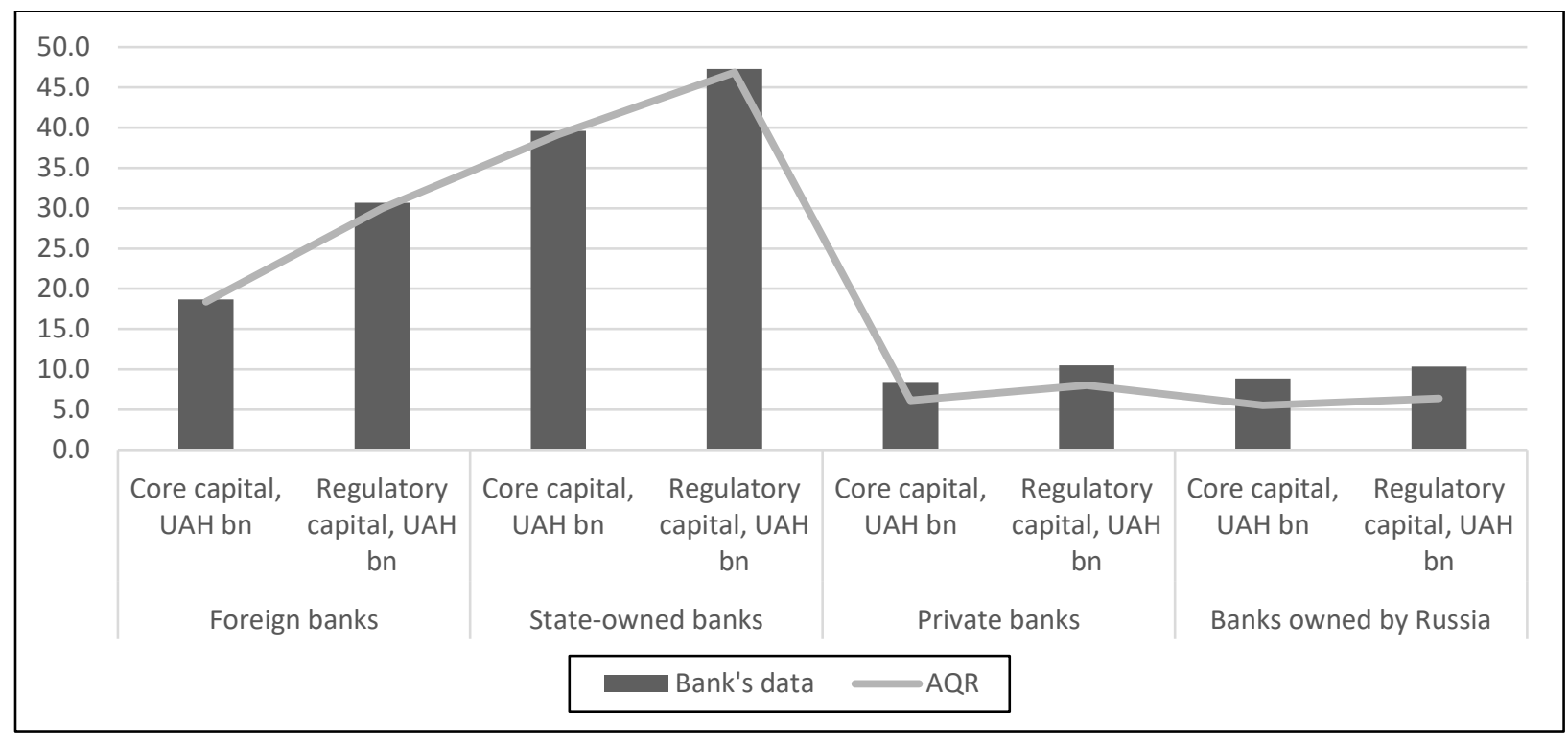

Figure 3: Core and Regulatory capital across groups of banks

Source: based on data 16 .

The excess of the core capital indicator, compared to AQR, according to the banks' estimate, is $1 \%$ for a group of Ukrainian stateowned banks, $2 \%$ for a group of foreign-owned banks, $36 \%$ for a group of private banks, and $61 \%$ for banks owned by Russia. 
The deviation between the banks' estimates and $\mathrm{AQR}$ by the regulatory capital indicator is $1 \%$ in the group of Ukrainian state-owned banks, $2 \%$ in the group of banks with foreign capital, $31 \%$ in the group of private banks, and $62 \%$ in banks with state-owned Russian capital.

Table 3: Diagnostic results H2, H3 (comparison across groups of banks) as of 01.01.18

\begin{tabular}{|l|c|c|c|c|c|c|c|c|}
\hline \multirow{2}{*}{ Indicator } & \multicolumn{2}{|c|}{ Foreign banks } & \multicolumn{2}{c|}{$\begin{array}{c}\text { State-owned } \\
\text { banks }\end{array}$} & \multicolumn{2}{c|}{ Private banks } & \multicolumn{2}{c|}{$\begin{array}{c}\text { All banks under } \\
\text { stress test }\end{array}$} \\
\cline { 2 - 9 } & $\mathrm{H} 2$ & $\mathrm{H} 3$ & $\mathrm{H} 2$ & $\mathrm{H} 3$ & $\mathrm{H} 2$ & $\mathrm{H} 3$ & $\mathrm{H} 2$ & $\mathrm{H} 3$ \\
\hline Bank's data & $16.9 \%$ & $10.3 \%$ & $16.4 \%$ & $13.7 \%$ & $11.6 \%$ & $9.3 \%$ & $15.5 \%$ & $11.9 \%$ \\
\hline AQR & $16.5 \%$ & $10.1 \%$ & $15.9 \%$ & $13.3 \%$ & $9.1 \%$ & $7.0 \%$ & $14.4 \%$ & $10.9 \%$ \\
\hline Forecast year & \multicolumn{7}{|c|}{ Baseline scenario } \\
\hline 1st & $18.9 \%$ & $16.9 \%$ & $22.3 \%$ & $16.1 \%$ & $8.7 \%$ & $7.3 \%$ & $17.8 \%$ & $14.1 \%$ \\
\hline 2nd & $25.0 \%$ & $23.5 \%$ & $27.8 \%$ & $21.7 \%$ & $11.8 \%$ & $10.5 \%$ & $22.4 \%$ & $18.9 \%$ \\
\hline 3rd & $31.7 \%$ & $30.5 \%$ & $34.0 \%$ & $28.4 \%$ & $16.2 \%$ & $15.1 \%$ & $27.9 \%$ & $24.7 \%$ \\
\hline Forecast year & \multicolumn{7}{|c|}{ Adverse scenario } \\
\hline 1st & $14.5 \%$ & $13.1 \%$ & $3.5 \%$ & $1.3 \%$ & $-4.1 \%$ & $-4.6 \%$ & $5.3 \%$ & $3.7 \%$ \\
\hline 2nd & $19.2 \%$ & $18.3 \%$ & $-0.1 \%$ & $-1.8 \%$ & $-6.2 \%$ & $-6.7 \%$ & $4.2 \%$ & $3.1 \%$ \\
\hline 3rd & $25.4 \%$ & $24.7 \%$ & $4.7 \%$ & $1.0 \%$ & $-3.1 \%$ & $-4.1 \%$ & $8.7 \%$ & $6.7 \%$ \\
\hline
\end{tabular}

* without Russia

According to the baseline scenario, banks should ensure that the minimum requirements for $\mathrm{H} 2-10 \%$ and $\mathrm{H} 3-7 \%$ are met. According to the adverse scenario, banks should ensure that
The results of 3 yrs. of forecasting the financial sustainability of the Ukrainian banking system under the baseline and adverse scenario for indicators $\mathrm{H} 2$ and $\mathrm{H} 3$ are presented in Table 3.

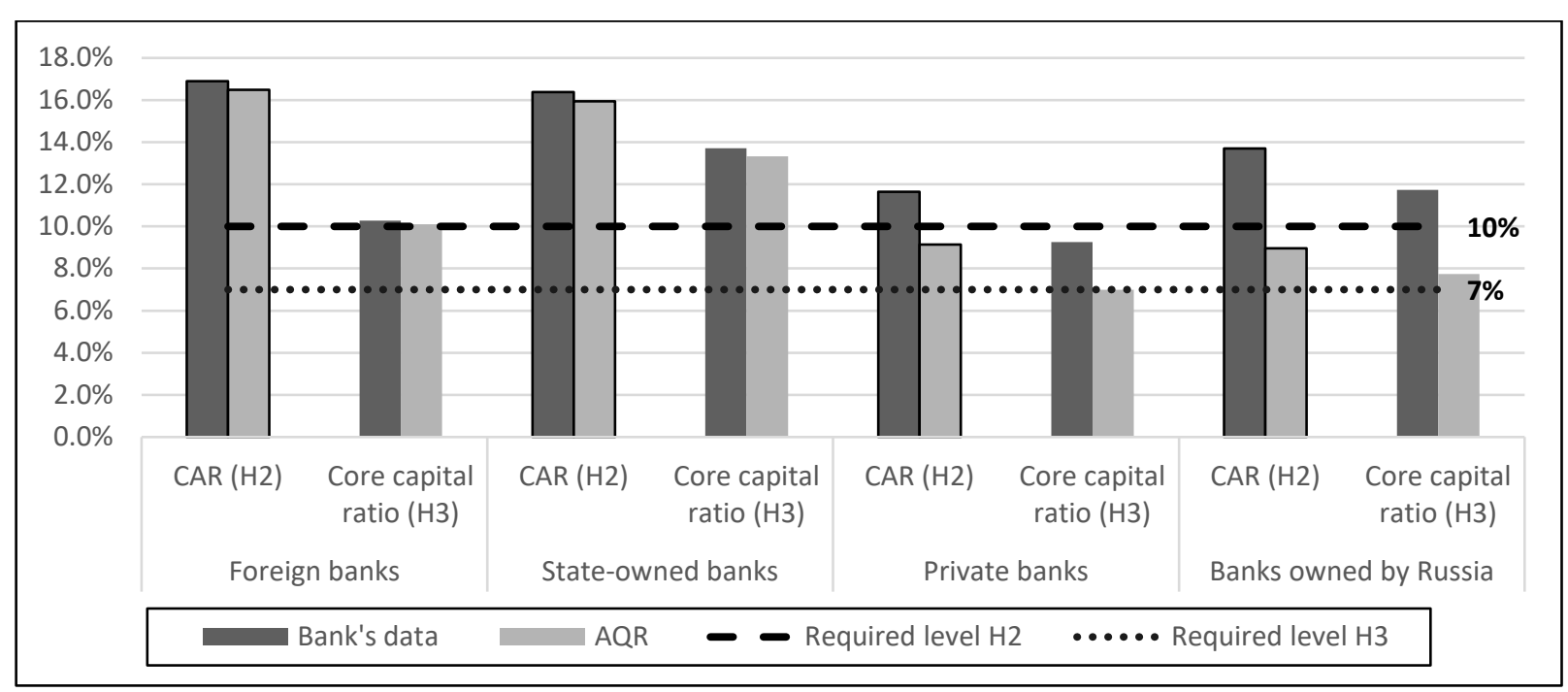

Figure 4: Diagnostic results of H2, H3 in groups of banks as of 01.01.18 Source: Developed by authors. 
According to the banks' data, the norms $\mathrm{H} 2$ and $\mathrm{H} 3$ in 2018 met the normative value. At the same time, the indicator $\mathrm{H} 2$ in the $A Q R$ result was not reached by the group of private Ukrainian banks and the group of state-owned Russian banks, accounting for $9.1 \%$ and $9.0 \%$, respectively, at the regulatory value of $10 \%$.

\section{Prospects for further research.}

The banking system is an important element of any country's economy. Today, many scholars and experts in the field of banking regulation consider the Basel III recommendations of the Basel Committee on Banking Supervision as effective tools to assess the financial stability of the banking system and to research the experience of stress testing in other countries.

The experience of Ukraine shows that the framework of stress testing should be clearly articulated and formally defined. Models and methodologies for assessing the impact and sensitivity of scenarios should be consistent with the purpose. The obtained results of stress testing confirm the conclusion that banks with foreign capital are the most stable in the Ukrainian banking system. A group of stateowned and Ukrainian private banks need special attention from the regulators.
According to the results of the stability assessment of banks, the necessary level of the regulatory capital adequacy ratio ( $\mathrm{H} 2<10 \%$, ) and the core capital adequacy ratio ( $\mathrm{H} 3<7 \%$, will be determined. The NBU stress testing baseline scenario, however, did not take into account the impact of the devaluation of the national currency.

Using the NBU baseline approach, stress testing was made for different groups of banks, taking into account the growth of the basic exchange rate of EUR/UAH. Modifications were suggested for the method of statistical analysis for the dynamics of the indicators of stress testing, employing the continuous model, which calculates the share of net assets of foreign banks in foreign currency for a different exchange rate, EUR/UAH.

In this case, the basic exchange rate EUR/UAH was estimated with an increase of $10 \%$, step by step. The method application was demonstrated by relying on the example of the comparison between the state-owned, Ukrainian, and foreign banks, including banks with capital from Eastern Europe and Central Asia*. The following are the received results of the updated stress testing approach, accounting for the increased exchange rate from $10 \%$ to $70 \%$ against the base rate.

Table 5: Indexes of stress testing in the banking system Ukraine for 01.10.2018

\begin{tabular}{|c|c|c|c|c|c|c|c|c|c|c|}
\hline $\begin{array}{l}\text { Group } \\
\text { of }\end{array}$ & \multirow[b]{2}{*}{$\begin{array}{l}\text { State- } \\
\text { owned }\end{array}$} & \multirow[b]{2}{*}{ Ukraine } & \multicolumn{7}{|c|}{ Foreign } & \multirow{2}{*}{$\begin{array}{c}\text { Total by } \\
\text { banking } \\
\text { system of } \\
\text { Ukraine }\end{array}$} \\
\hline Index & & & Russia & $\begin{array}{c}\text { Western } \\
\text { Europe }\end{array}$ & $\begin{array}{l}\text { Southe } \\
\text { rn } \\
\text { Europe }\end{array}$ & $\begin{array}{l}\text { Eastern } \\
\text { Europe } \\
\text { and } \\
\text { Central } \\
\text { Asia* }\end{array}$ & $\begin{array}{l}\text { West Asia } \\
\text { and } \\
\text { Southern } \\
\text { Europe }\end{array}$ & USA & $\begin{array}{l}\text { Cyprus } \\
\text { offshore }\end{array}$ & \\
\hline $\begin{array}{l}\text { \# of } \\
\text { banks }\end{array}$ & 5 & 51 & 3 & 7 & 2 & 4 & 2 & 1 & 2 & 77 \\
\hline \multicolumn{11}{|c|}{ The number of banks with $\mathrm{H} 2<10 \%$, when the national currency devaluation } \\
\hline Basic & 0 & 2 & 0 & 0 & 0 & 0 & 0 & 0 & 0 & 2 \\
\hline$+10 \%$ & 0 & 2 & 0 & 0 & 0 & 0 & 0 & 0 & 0 & 2 \\
\hline$+20 \%$ & 0 & 2 & 0 & 0 & 0 & 0 & 0 & 0 & 0 & 2 \\
\hline$+30 \%$ & 0 & 2 & 0 & 0 & 0 & 0 & 0 & 0 & 0 & 2 \\
\hline$+40 \%$ & 0 & 2 & 0 & 0 & 0 & 0 & 0 & 0 & 0 & 2 \\
\hline
\end{tabular}


Table 5. Continuous

\begin{tabular}{|c|c|c|c|c|c|c|c|c|c|c|}
\hline$+50 \%$ & 0 & 3 & 0 & 0 & 0 & 0 & 0 & 0 & 0 & 3 \\
\hline$+60 \%$ & 0 & 3 & 0 & 0 & 0 & 0 & 0 & 0 & 0 & 3 \\
\hline$+70 \%$ & 0 & 3 & 2 & 0 & 0 & 0 & 0 & 0 & 0 & 5 \\
\hline \multicolumn{11}{|c|}{ The number of banks with $\mathrm{H} 3<7 \%$, when the national currency devaluation } \\
\hline Basic & 0 & 2 & 0 & 0 & 0 & 0 & 0 & 0 & 0 & 2 \\
\hline$+10 \%$ & 0 & 2 & 0 & 0 & 0 & 0 & 0 & 0 & 0 & 2 \\
\hline$+20 \%$ & 1 & 2 & 0 & 0 & 0 & 0 & 0 & 0 & 1 & 4 \\
\hline$+30 \%$ & 1 & 5 & 0 & 0 & 0 & 0 & 0 & 0 & 1 & 7 \\
\hline$+40 \%$ & 1 & 6 & 0 & 0 & 0 & 0 & 0 & 0 & 1 & 8 \\
\hline$+50 \%$ & 1 & 6 & 1 & 1 & 0 & 0 & 0 & 0 & 1 & 10 \\
\hline$+60 \%$ & 3 & 8 & 1 & 1 & 0 & 1 & 0 & 0 & 1 & 15 \\
\hline$+70 \%$ & 4 & 12 & 1 & 3 & 0 & 2 & 0 & 0 & 2 & 24 \\
\hline \multicolumn{11}{|c|}{ The need for capital, when the national currency devaluation (million UAH) } \\
\hline Basic & 0 & 543,766 & 0 & 0 & 0 & 0 & 0 & 0 & 0 & 543,766 \\
\hline$+10 \%$ & 0 & 567,426 & 0 & 0 & 0 & 0 & 0 & 0 & 0 & 567,426 \\
\hline$+20 \%$ & 87,331 & 599,972 & 0 & 0 & 0 & 0 & 0 & 0 & 106,543 & 793,845 \\
\hline$+30 \%$ & 762,218 & 712,342 & 0 & 0 & 0 & 0 & 0 & 0 & 410,872 & $1,885,432$ \\
\hline$+40 \%$ & $1,662,068$ & $1,195,863$ & 0 & 0 & 0 & 0 & 0 & 0 & 816,645 & $3,674,575$ \\
\hline$+50 \%$ & 2,921,857 & $1,889,091$ & 294,114 & 31,952 & 0 & 0 & 0 & 0 & $, 384,726$ & $6,521,740$ \\
\hline$+60 \%$ & 7,307,712 & $3,197,922$ & 937,226 & 407,508 & 0 & 4,655 & 0 & 0 & $2,236,849$ & $14,091,871$ \\
\hline$+70 \%$ & $15,888,956$ & $6,193,015$ & $2,010,371$ & $2,125,516$ & 0 & 512,621 & 0 & 0 & $\beta, 930,469$ & $30,660,948$ \\
\hline \multicolumn{11}{|c|}{ The need for capital, when the national currency devaluation (million EUR**) } \\
\hline Basic & 0 & 19,260 & 0 & 0 & 0 & 0 & 0 & 0 & 0 & 19,260 \\
\hline$+10 \%$ & 0 & 20,098 & 0 & 0 & 0 & 0 & 0 & 0 & 0 & 20,098 \\
\hline$+20 \%$ & 3,093 & 21,250 & 0 & 0 & 0 & 0 & 0 & 0 & 3,774 & 28,117 \\
\hline$+30 \%$ & 26,997 & 25,230 & 0 & 0 & 0 & 0 & 0 & 0 & 14,553 & 66,780 \\
\hline$+40 \%$ & 58,868 & 42,356 & 0 & 0 & 0 & 0 & 0 & 0 & 28,925 & 130,149 \\
\hline$+50 \%$ & 103,488 & 66,909 & 10,417 & 1,132 & 0 & 0 & 0 & 0 & 49,045 & 230,992 \\
\hline$+60 \%$ & 258,830 & 113,266 & 33,195 & 14,433 & 0 & 165 & 0 & 0 & 79,226 & 499,116 \\
\hline$+70 \%$ & 562,767 & 219,349 & 71,205 & 75,283 & 0 & 18,156 & 0 & 0 & 139,212 & $1,085,972$ \\
\hline
\end{tabular}

*without Russia and Ukraine

**NBU exchange rate 01.10.18 2823.3641 UAH = 100 EUR

Source: Developed by authors. 
The bank system in Ukraine includes 77 banks: 5 state-owned banks, 51 private Ukrainian banks, and 21 foreign banks. Foreign banks include 7 subgroups: 7 banks owned by Western European nations, 4 banks owned by Eastern European and Central Asian countries*, 3 banks owned by Russia, 2 banks owned by Southern European countries, 2 banks owned by Western Asian countries and Southern European countries, 2 banks owned by Cyprus offshore companies, and 1 bank owned by the USA.

The results of the updated stress testing approach showed significant differences between the $\mathrm{H} 2$ and $\mathrm{H} 3$ norms. According to the data, almost all banks (except 2-3 Private Ukrainian banks) comply with $\mathrm{H} 2$ norms in the case of increasing the exchange rate from $10 \%$ to $60 \%$ against the base rate. A completely different situation was observed with the $\mathrm{H} 3$ norm. One state-owned bank and two private Ukrainian banks did not comply with $\mathrm{H} 3$ norms in the case of increased exchange rates from $20 \%$. One state-owned bank and five private Ukrainian banks did not comply with $\mathrm{H} 3$ norms in the case of increased exchange rates from 30\%. Three state-owned banks, eight private Ukrainian banks, and three foreign banks did not comply with $\mathrm{H} 3$ norms in the case of an increased exchange rate from $60 \%$.

The results of the updated stress testing approach showed significant differences between groups of banks. Foreign banks have better results of stress testing than private Ukrainian banks and state-owned banks. As of the beginning of 2018, accounting for the basic exchange rate, two private Ukrainian banks did not comply with $\mathrm{H} 2$ and $\mathrm{H} 3$ norms, needing 543,766 mln. UAH (19 $260 \mathrm{mln}$. EUR). Banks with foreign capital comply with norms $\mathrm{H} 2$ and $\mathrm{H} 3$ in the forecasts for $10 \%, 20 \%, 30 \%$ and $40 \%$ increases in the exchange rate.

In the group of banks with foreign capital, the least optimal indicators are in Eastern Europe and Central Asia,* not including banks owned by Russia and Ukraine. The Eastern European and Central Asian* group included 4 banks: OTP Bank (Hungary), Kredobank (Poland), Idea Bank (Poland), and BTA Bank (Kazakhstan). OTP Bank (Hungary) has 86 branches, Kredobank (Poland) has 93 branches, Idea Bank (Poland) has 82 branches, and BTA Bank (Kazakhstan) has one head office in Kyiv. The return on equity (ROE), core capital (CC), and regulatory capitals (RC) of banks from Eastern Europe and Central Asia are presented in Table 6.

Table 6: Indicators Eastern European and Central Asian bank group as of 01.01.18

\begin{tabular}{|l|c|c|c|c|}
\hline \multicolumn{1}{|c|}{ Indicator } & $\begin{array}{c}\text { OTP Bank } \\
\text { (Hungary) }\end{array}$ & $\begin{array}{c}\text { Kredobank } \\
\text { (Poland) }\end{array}$ & $\begin{array}{c}\text { Idea Bank } \\
\text { (Poland) }\end{array}$ & $\begin{array}{c}\text { BTA Bank } \\
\text { (Kazakhstan) }\end{array}$ \\
\hline ROE, \% & 37.57 & 25.01 & 46.81 & 3.6 \\
\hline CC, mln. UAH & 2,444 & 880 & 218 & 348 \\
\hline RC, mln. UAH & 3,234 & 1,411 & 436 & 360 \\
\hline
\end{tabular}

Only two -- Idea Bank and BTA Bank - will have capital needs (total 18,156 mln EUR), when national currency devaluation is more than $70 \%$. This is 4 times less than the need for capital for Russian owned banks (total 71,205 mln. EUR), and 12 times less than Ukrainian private banks (total 219,349 mln. EUR).

Thus, devaluation of the national currency significantly influences the $\mathrm{H} 2$ norm, especially the $\mathrm{H} 3$ norm. Therefore, stability assessment should take into account changes in the exchange rate, and stress testing of the banking system in Ukraine should consider three groups of banks: state owned banks, private Ukrainian banks, and foreign banks.

\section{CONCLUSIONS AND RECOMMENDATIONS}

The introduction of a tool such as stress testing, allows the identification of both current and future risks for banks, as well as to form their own capital that is sufficient to minimize future risks. It will enhance the stability of the 
banking system and protect the interests of depositors and bank lenders.

The research of specific features and approaches to stress testing banks in Ukraine permitted the identification of some negative and some positive tendencies, determining the following aspects of the formation of the strategy of banking stress testing:

- To concentrate on further implementation of the Basel III recommendations in the banking system of Ukraine using the experience of foreign banks, especially European banks

- To work out the concept of state regulation of foreign banking development in Ukraine, as well as criteria for entry and exit from the Ukrainian banking market.

- The stress testing framework should have well-formulated and officially adopted goals, according to which developing and implementing a strategy of strengthening the positions of Ukrainian banks is necessary, as is the identification of systemically important banks;

- Models and methodologies for assessing the impact of scenarios should also be updated, and stress testing should take into account changes in the national currency exchange rate;

- Stress testing models, results, and frameworks should be questioned and reviewed regularly, including the required levels of indicators (H2) and (H3);

- Stress testing results should be made public and used as a risk management tool, as well as an instrument of information about business decisions.

Asset quality assessment and stress testing are a permanent practice of leading international financial organizations. These provide opportunities to prevent excessive accumulation of systemic risks and prepare banks for possible future crises. The conclusions and proposals received based on the research on Ukraine's experience will not only improve the financial stability of the Ukrainian banking system but will also ultimately contribute to overall financial stability.

\section{REFERENCES}

Bookstaber, R., Cetina, J., Feldberg, G., Flood, M., Glasserman P. (2014). Stress Tests to Promote Financial Stability: Assessing Progress and Looking to the Future. Journal of Risk Management in Financial Institutions, 7(1), pp. 16-25

Covas, F., Rump, B., Zakrajsek, E. (2014). Stress-testing U.S. Bank Holding Companies: A Dynamic Panel Quantile Regression Approach. International Journal of Forecasting, 30(3), pp. 691-713

Diuba, Yu., Murina, H., (2015). The NBU Approach to Stress Testing the Ukrainian Banking System. The Bulletin of the National Bank of Ukraine, 234, pp. 39-51

Hirtle, B., Kovner, A., Vickery, J., Bhanot, M. (2016). Assessing financial stability: The Capital and Loss Assessment under Stress Scenarios (CLASS) Model. Journal of Banking and Finance, 69 (S1), pp. 535-555.

Kapinos, P., Mitnik, O., Martin, C. (2018). Stress Testing Banks: Whence and Whither? Journal of Financial Perspectives, 5(1), pp. 68-87.

Kichurchak, M. (2019). Bank deposit activity in Ukraine: directions and factors of development activation. Journal of Eastern European and Central Asian Research, 6 (1), pp. 145-160

Maslennikov, E., Lomachynska, I., Bychkova, N. (2017). Ensuring the stability of the Ukrainian banking system in the context of institutional transformation. Scientific bulletin of Polissia, 4 (12), pp. 62-70

National Bank of Ukraine. Official web site, Statistical data and various reports. Retrieved August 21, 2019, from https://bank.gov.ua/control/uk/.

Ramskyi, A., Loiko, V., SobolievaTereshchenko, O., Loiko, D., Zharnikova, V. (2017). Integration of Ukraine into the European banking system: cleaning, rebooting and Basel III, Journal of Banks and Bank Systems, 12(4), pp.163-174

Reverchuk, S., Vladychyn, U., Davis, Ch. (2015). Foreign Banking in Ukraine: Development Trends and Ownership Structure Regulation. Journal of Eastern European and Central Asian Research, 2 (2), pp. 1-14 
Sangha, B., Lin, J. (2013). Stress-testing Models: A Strategic Risk Management Tool. Journal of Financial Perspectives, 1(2), pp. 1-9

Schuermann, T. (2014). Stress Testing Banks, International Journal of Forecasting, 30(3), pp. 717-728.

Sobolieva-Tereshchenko, O. (2018). The Bank Card Market: A Comparative Analysis of Ukraine and its Neighboring Countries.

Comparative Economic Research, 21(4), pp.2544

Wall, L. (2014). Measuring Capital Adequacy: Supervisory Stress-Tests in a Basel World, Journal of Financial Perspectives, 2(1), pp. 85-94

The World Bank (2019), Foreign Banks Among Total Banks (\%) Retrieved from https://datacatalog.worldbank.org/foreignbanks-among-total-banks

National Bank of Ukraine (2019). Financial indicators of Ukraine's financial reporting. Retrieved from: https://bank.gov.ua/control/uk/publish/article?a rt_id=34661442\&cat_id=34798593

\section{ABOUT THE AUTHORS}

Olena Sobolieva-Tereshchenko, email: s8000@i.ua

Dr. Olena Sobolieva-Tereshchenko, possesses Ph.D. in Economics, Associate Professor, currently works at the Department of Finance and Economics, Borys Grinchenko Kyiv University. She has 15 years of banking experience, 9 years of experience teaching in various Ukrainian universities. Dr. SobolievaTereshchenko is an author of a many scientific papers, three scientific monographs published in peer-review journals. Her main scientific interests are in the field of national economy development, finance, loyalty systems, accounting, analysis, and banking.

Dr. Yuliia Zhukova, is an Associate Professor and holds a Ph.D. in Economics. Currently works in the Department of Finance and Economics, at Borys Grinchenko Kyiv University. Dr. Zhukova has a 21-years of teaching experience in multiple Ukrainian universities. She has published multiple articles in the field of macroeconomic policy and economic growth. 